\title{
Henryk PIETRAS SJ, L'Escatologia della Chiesa dagli scritti giudaici fino al IV secolo, Sussidi Patristici 13, Roma 2006, Istituto Patristico „Augustinia- num", ss. 140.
}

Nie jest to podręcznik pełnej eschatologii patrystycznej, ale publikacja zawierająca wybrane jej zagadnienia, od eschatologii żydowskiej czasów Chrystusa po IV wiek, udokumentowana licznymi konkretnymi wypowiedziami tego okresu. W przeciwieństwie do książki Briana E. Daley'a SJ, The hope of the Early Church. A handbook of patristic Eschatology (Cambridge 1991, Cambridge University Press, ss. XIV + 300; zob. wcześniej: Eschatologie in der Schrift und Patristik, unter Mitarbeit von J. Schreiner - H.E. Lona, HDG IV 7a, Freiburg - Basel - Wien 1986, s. 84-248: Patristiche Eschatologie), która uchodzi aktualnie za klasyczny podręcznik eschatologii patrystycznej, prezentujący naukę Kościoła o rzeczach ostatecznych u poszczególnych autorów wczesnochrześcijańskich, bez cytowania jednak ich wypowiedzi, ale $z$ dołączeniem związanej z ich imieniem bibliografii (opracowań), pogrupowanych chronologicznie pod XII hasłami (np. I. Visions of a new day: early Semitic Christianity and Christian apocalyptic [...] XI. Apocatastasis and apocalyptic: eastern eschatology after Chalcedon; XII. The end of all flesh: eschatology in the sixthcentury West) aż po Jana Damasceńskiego na Wschodzie i Grzegorza Wielkiego na Zachodzie, publikacja ta ogranicza przedstawianie tej tematyki do pierwszych czterech wieków, czyni to wokół pewnych wybranych zagadnień, a przez liczne cytaty pozwala na ten temat przemawiać Ojcom Kościoła ich własnym językiem. Pisze zresztą o tym Autor we wstępie, że „ograniczy się do tematów ważniejszych, do autorów, którzy do tej dziedziny więcej wnieśli, do myśli, które wzbudzają dyskusję. Wybór tematów - stwierdza - jest $z$ pewnością dowolny, i niejeden $z$ badaczy zauważy brak pewnych poglądów przez niego uznawanych za ważne; to jednak, co będzie się starał przedstawić, będzie prezentował w oparciu o teksty, aby lepiej przybliżyć czytelnikowi język Ojców" (s. 5). I tych założeń stara się nasz Autor przestrzegać w swojej książce rozpoczynając prezentację eschatologii Ojców Kościoła od eschatologii żydowskiej czasów Jezusa z nielicznymi odniesieniami do Starego Testamentu, a z liczniejszymi do apokryfów międzytestamentalnych, czyli tekstów religijności ludowej, kończąc swój wykład na omówieniu poglądów Grzegorza z Nyssy i Augustyna, z których pierwszy wpłynął wielce na późniejszą teologię eschatologiczną Wschodu, a drugi - Zachodu.

Tak zarysowaną tematykę przedstawia ks. prof. H. Pietras w swej książce złożonej z dziewięciu rozdziałów: w rodz. I: Eschatologia żydowska czasów Jezusa (s. 7-20) przypomniane są najpierw pierwsze wzmianki o nadziei życia pozagrobowego i wiary w zmartwychwstanie, potem o nagrodzie pośmiertnej w opinii Esseńczyków, etiopskiej i słowiańskiej Księgi Henocha oraz IV Księgi Ezdrasza, a wreszcie o oczekiwaniu Mesjasza pojmowanego dwojako w czasach 
Jezusa, zapowiadanego w IV Księdze Ezdrasza. W rozdz. II: Pierwszy millenaryzm wedtug Apokalipsy 20 (s. 21-26) omówione sq pierwsze ślady millenaryzmu, zauważane w pismach Nowego Testamentu i w apokryfach. W rozdz. III: „Już, a jeszcze nie” u Ojców Apostolskich (s. 27-36) jest mowa o zbawieniu wybranych, o modlitwie za zmarłych i o wiecznym szabacie w oparciu o List Pseudo-Barnaby, Pasterza Hermasa, Pasje Perpetui i Felicyty, II List Klemensa Rzymskiego i List do Diogneta. W rozdz. IV: Zstapienie do piekiet-poczqtek artykułu wiary (s. 37-46) Autor opisuje zstąpienie dusz do piekieł w oparciu o apokryfy Nowego Testamentu (Ewangelia Piotra, Ody Salomona, Ewangelia Barnaby, Ewangelia Nikodema) i wypowiedzi najstarszych pisarzy chrześcijańskich (Konstytucje Apostolskie, Hermas, Justyn, Klemens Aleksandryjski, Ireneusz, Hipolit i Orygenes). W rozdz. V: Wptyw dualizmu antropologicznego (s. 47-56) jest mowa o człowieku jako bycie złożonym z ciała i duszy - podmiocie eschatologii chrześcijańskiej w oparciu o platońskiego Fedona, traktatów $O$ zmartwychwstaniu Pseudo-Justyna i Atenagorasa z Aten, oraz pisma Ireneusza z Lyonu. W rozdz. VI: Drugi millenaryzm (s. 57-76) Autor charakteryzuje millenarystyczne zapatrywania Ireneusza i Tertuliana omawiając przy tym poglądy tego drugiego o cielesności duszy, o stopniowym zmartwychwstaniu w tysiącleciu i o sądzie ostatecznym. W rozdz. VII: Tematy orygenesowskie (s. 77-96) nasz Autor porusza takie wybrane zagadnienia z eschatologii Orygenesa, jak: krytyka ,materializmu”, pierwsze zmartwychwstanie, szkoła dusz, serie światów, sąd ostateczny, "drugie zmartwychwstanie" i apokatastaza. W rozdz. VIII: Powszechne zbawienie wedtug Grzegorza z Nyssy (s.97-104) omawia takie punkty jego eschatologii, jak: natura piekła, i apokatastaza jako powrót do pierwotnego stanu. Wreszcie w rozdz. IX: Augustyn z Hippony $i$ zbawienie przeznaczonych (s. 105-118) charakteryzuje jego poglądy o millenaryzmie, o zmartwychwstałych ciałach, o losie potępionych, o niemożliwości apokatastazy, o największej radości wiecznej, oraz o różnorodności kar pośmiertnych, a wśród nich i dzieci nieochrzonych. W Zakończeniu (s. 119-121) Autor stawia ważne według niego pytanie: „Dlaczego starożytni czuli się zobowiązani do przedstawiania eschatologii w sposób chronologiczny, to znaczy, dlaczego wiara w zmartwychwstanie wymaga wysiłku wyobrażania sobie, jakoby wszystkie rzeczy miały się toczyć między śmiercią a zmartwychwstaniem?". Odpowiadając zaś na nie zaznacza: „Odpowiedź leży w pojęciu czasu. Starożytni rozumieli go jako rzeczywistość transcendentną, w której zanurzone jest wszystko to, co istnieje, od początku świata aż do końca, jakby się było rzeką, która ma swe źródła w stworzeniu, a koniec - w oceanie wieczności" (s. 117).

$\mathrm{Z}$ przedstawionego wyżej szczegółowego przeglądu treści omawianej publikacji widać, że jej Autor faktycznie starał się w niej przedstawić nie tyle całą systematyczną eschatologię patrystyczną do końca IV wieku, ile wybrane z niej, niekiedy dyskusyjne, zagadnienia, na których temat rozmawia $\mathrm{z}$ wybranymi autorami wczesnochrześcijańskimi. Książka zakończona jest Bibliografia (s. 
123-152) podzieloną tradycyjnie na źródła i najnowsze opracowania. Szkoda, że Autor oprócz 5 swoich tylko szczątkowo wymienia inne polskie publikacje (B. Górka - 1, W. Myszor - 1, M. Szram - 1), a z najnowszych można by jeszcze wyliczyć inne związane z omawianym okresem, choćby opublikowane w 19 tomie „Vox Patrum” w 1990 r. prelekcje wygłoszone (18-19 IX 1990) na dorocznym spotkaniu Sekcji Patrystycznej w Koszalinie o eschatologii Ojców Kościoła (T. Kaczmarek - Los sprawiedliwych Starego Testamentu po śmierci wedtug świadectw I-II wieku, s. 589-598; K. Obrycki - Los złych do śmierci wedtug Tertuliana, s. 599-608; J. Wojtczak - Eschatologiczne koncepcje Laktancjusza w VII księdze „Divinae Institutiones”, s. 609-620; B. Częsz - Interpretacja nieba w kategorii Państwa Bożego przed św. Augustynem, s. 621-636; S. Longosz - Eschatologia Ojców Kościoła, s. 973-975). Choć książka napisana po włosku przeznaczona jest głównie dla czytelników zagranicznych, to niechby i oni dowiedzieli się, ze i Polacy na temat eschatologii patrystycznej mają niemałą literaturę. Całość omawianej publikacji, wydanej przez Instytut Patrystyczny „Augustinianum” jako „pomoc dydaktyczna”, zakończona jest indeksami: biblijnym (s. 133), cytowanych źródeł (s. 133-136) i autorów nowożytnych (s. 136-137). Trzeba się cieszyć, że książka ks. prof. dra hab. Henryka Pietrasa, polskiego patrologa, znalazła uznanie Instytutu Patrystycznego i została wydana jako pomoc dydaktyczna dla jego studentów.

Ks. Stanisław Longosz - Lublin, KUL 